\title{
Renewables get mature
}

\section{Recent announcements highlight the increasing competitiveness of renewable electricity sources and signal that the need for subsidies may be approaching an end.}

If we were told just a few years ago that Saudi Arabia was planning to launch a large renewables power programme that envisaged investment worth US\$30bn-50bn by 2030 we would have been forgiven for thinking it was science fiction or the fantasy of a daydreamer. However, this is exactly what was announced in mid-January ${ }^{1}$. Similar activities are taking place in most countries around the world, confirming that our societies are becoming increasingly familiar with the idea that fossil fuels are not necessarily the default option when it comes to energy.

Further confirmation that renewable energy sources are finally reaching the age of maturity comes from the European Commission's (EC) recent Winter Package ${ }^{2}$, which consists of numerous legislative proposals aimed at further completing the Internal Energy Market (IEM) for electricity and implementing the Energy Union.

Although it is still subject to further scrutiny by the European Parliament and the Member States, the long-awaited package addresses a great number of important aspects of the future EU IEM, and indicates the main priorities and objectives that will shape the future of European electricity markets. More specifically, the package seeks to speed up the clean energy transition by prioritizing two areas of interventions: energy efficiency and electricity market design.

Energy efficiency is considered one of the core principles of the Energy Union. The 2016 Winter Package has set a binding goal of 30\% energy efficiency (expressed in primary or final energy consumption compared to the baseline year) by 2030. This target will be met through a number of approaches including new policies, better financing of energy efficiency conditions, strengthening the scope of requirements on products, vehicles and buildings, and greater consumer involvement.

Regarding electricity market design, the Winter Package aims to ensure a level playing field between renewable and fossil fuel technologies. Currently, renewable energy plants get priority dispatch, established as part of the 2009 Renewable Energy Directive ${ }^{3}$. This means that electricity generated from renewable energy sources has priority access to the grid ahead of electricity generated from fossil fuels. To compensate for the subsequent reduced profitability of traditional fossil fuel generators, and to ensure system reliability given renewable intermittency, capacity mechanisms were also introduced. Capacity mechanisms are payments, in addition to the wholesale market prices, that accrue to fossil fuel generation capacity kept available regardless of actual generation. The Winter Package will abolish priority dispatch so that renewable sources have to bid for access alongside fossil sources. It also will introduce more severe rules on capacity mechanisms. The Winter Package envisages that capacity payments will be gradually reduced for the most polluting plants and will be reserved for those units with lower emissions. At the same time, the package will increase the necessity for cross-border coordination in the determination of new capacity payments.

\section{Our societies are becoming increasingly familiar with the idea that fossil fuels are not necessarily the default option when it comes to energy.}

Taken together, these measures suggest that the low carbon transition in the energy system will now need to seriously consider the affordability of renewable energy sources and the distortions that they cause to electricity markets by not being subject to market dynamics. While some ${ }^{4}$ consider this process potentially dangerous for the sustained deployment of renewables in the EU Member States, it could also be considered an indirect acknowledgement of the competitiveness that new renewable energy generation technologies have reached globally.

The outgoing president of the United States, Barack Obama, recently echoed this sentiment ${ }^{5}$. In his opinion market forces are providing a powerful boost to clean energy, above and beyond public support. His words could certainly be interpreted as wishful thinking in the face of the forthcoming Trump presidency, which indeed appears to be less committed to climate change and the low carbon transition ${ }^{6}$. However, the many signals stemming from large private and public investors operating in mature ${ }^{7}$ and emerging ${ }^{1,8,9}$ economies suggest that this optimism could be justified, for at least two reasons. First, because expectations play a major role in market dynamics ${ }^{10}$, and thus the continually decreasing cost for low carbon technologies is drawing investments across the board. Second, the global consensus about the consequences of climate change $^{11}$ represents a powerful incentive to accelerate the technology transition before irreversible threats become even more costly and disruptive.

While energy policies are subject to great uncertainties and could easily swing depending on public consensus and political priorities, market dynamics - even with all their imperfections - seem likely to offer greater stability for the development of renewable generation in the coming years, particularly if technology innovation sets a clear cost advantage in a subsidyfree environment. As they approach grid parity, renewable energy sources will be increasingly called upon to contribute to energy security and network stability without causing an unsustainable increase in electricity bills, while also providing the necessary ancillary and systems reliability services currently offered by fossil fuel sources. The EC's Winter Package sets the perspective that those widespread incentives for renewable technologies might shortly come to an end, reminding us that the threshold of adulthood is getting closer for clean energy technologies.

\footnotetext{
References

1. Saudi Arabia seeks $\$ 30 \mathrm{bn}-\$ 50 \mathrm{bn}$ solar and wind energy investment. Financial Times (16 January 2017); http://go.nature.com/2jVxIq6

2. Commission Proposes New Rules for Consumer Centred Clean Energy Transition (European Commission, 2016).

3. Directive 2009/28/EC of the European Parliament and of the Council (European Union, 2009).

4. Renewables could lose European power grid priority, documents reveal. The Guardian (1 November 2016); http://go.nature. $\mathrm{com} / 2 \mathrm{k} 5 \mathrm{sDOb}$

5. Obama, B. Science 355, 126-129 (2017)

6. Giberson, M. Nat. Energy 1, 16156 (2016)

7. Economic Report of the President (Council of Economic Advisers, 2017).

8. China to invest $£ 292 \mathrm{bn}$ in renewable power by 2020 . The Guardian (5 January 2017).

9. India plans nearly $60 \%$ of electricity capacity from non-fossil fuels by 2027. The Guardian (22 December 2016).

10. Jaffe, A. M. Nat. Energy 1, 16158 (2016).

11. Marrakech Action Proclamation for our Climate and Sustainable Development (UNFCCC, 2016)
} 


\section{Correction: Renewables get mature}

Nature Energy 2, 17017 (2017); published 9 February 2017; corrected 6 March 2017.

In the version of this Editorial originally published, references 6 and 10 were incorrect. The correct references are given below. These errors have been corrected in all versions of the Editorial.

6. Giberson, M. Nat. Energy 1, 16156 (2016).

10. Jaffe, A. M. Nat. Energy 1, 16158 (2016). 